\title{
The Antecedents Of Effective Mobile Marketing For Strengthening Consumers' Chances Of Mobile Marketing Acceptance.
}

\author{
Alaa Elsayed Elsayaad*
}

*Alaa Elsayed Elsayaad Teaching Assistant at Management Sciences Department -Faculty of Technology and Development- Zagazig University. Research interests are in (marketing, international trade, negotiation, e-commerce, and human resource management. 


\section{Abstract:}

This research investigates factors that may affect the level of acceptance of mobile marketing and determines if there is a relationship between these factors and level of acceptance of mobile marketing. It separately investigates the most influential factors affecting the level of acceptance. This research was to investigate as well if there were differences in the readiness of undergraduate students regarding acceptance and factors leading to acceptance in terms of gender, age, education and place. The research depends upon a sample of undergraduate students studying in universities. The researcher employed statistical techniques such as descriptive, correlation analysis, linear multiple regression, one-way ANOVA, and the post hoc test. The main findings from this research are that factors affecting acceptance were related to the level of acceptance of mobile marketing in the research field of reality. There is a significant difference between undergraduate students regarding factors affecting acceptance of mobile marketing; also there is a significant difference between undergraduate students regarding their readiness of acceptance in terms of some demographic characteristics.

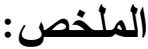

يتناول هذا البحث في إطار منهجي موضوع العوامل المؤثره على إستعدا العملاء لقبول التسويق عبر الهاتق الدحمول والتعرف على الأسباب التى تدفع مستخدمي الهاتق الدحمول إلى قبول التسويق عبرالهاتق الدحمول ـ عن طريق تصميم إستقصاء وأستخدام البيانات لأختبار الفروض ـ قامت الباحثه التهاب

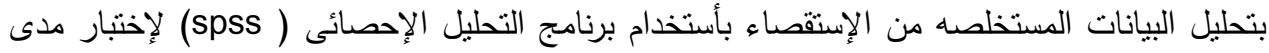
معنويه وقوه العلاقه بين متغيرات الدراسه منل التحليل الوصفى لدفردات العينه تحليل الإرتباط وتحليل

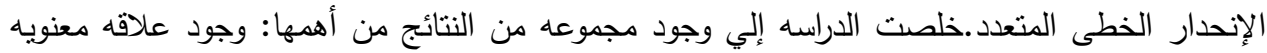
ذات دلاله إحصائيه بين العوامل المؤثره على إستعداد العملاء وقبول التسويق عبر الهاتف المحمول كما لإنا

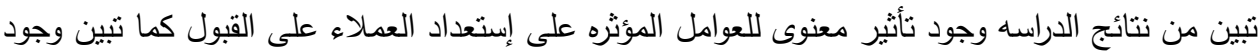
أختلافات معنويه بين إستعداد طلاب الجامعات نحو القبول وفقاً لخصائصهم الديموغرافيه كالنوع والسن والتعليم ومحل الإقامه. 


\section{Introduction}

As technology continues to advance, communication channels will continue to grow and change. Since its launch, the internet has conquered all the aspects of human life. The way people access information, share information, communicate, and interact with each other has been drastically modified. In addition, the internet contributed erasing geographical barriers and reducing the factors of space and time.

Driven by the fast changing technological developments, today's business environment has viewed increased mobility and an obvious increase in the use of mobile devices by consumers. In light of these developments, mobile marketing industry has grown significantly and is set to continue growing (Persaud \& Azhar, 2012).

The high global penetration of mobile communication devices is only one indicator of the high potential of marketing via mobile. Moreover, the specific characteristics of the mobile phone allow for marketing measures not realizable by the use of other media.

Thus, marketing via mobile supports both the marketers and consumers because marketers can increase their client base as they can access several consumers of different identities and various geographical areas, while consumers will also have a wide range of products choices .Also marketing via mobile is still at its opening but has an immense potential to grow as the environment experiences further technological advancements (Chinomona \& Sandada 2013). So,the purpose of this study is to gain more understanding about the factors of the mobile marketing acceptance, these factors are drawn from Two theoretical areas (the technology acceptance model (TAM) and uses and gratifications theory) which study the interaction between users and technology, and have been widely applied in the marketing literature to explain individual behavior related to the adoption and usage of technology.

(1.1) Research framework:

\section{1- Research Problem:}

As marketing via mobile is a promising strategy, several facts can explain why marketing via mobile works as a kind of framework, 
a glue between all the other media (points of sale, events, TV, radio outdoor, online etc.).

This strategy recorded an $82.8 \%$ growth rate in advertising through mobiles during 2012, with 7.5 billion users in 2014 that reached 8.5 billion users by the end of 2016 (Internet Advertising Bureau - iab).

Moreover, marketing via mobile spending in Middle East and North Africa reached 85 million and 50 million euro in 2012 and 2013 respectively. The Egyptian ministry of communication reported that from October 2015 to November 2015 the mobile subscription increased from 93.13 million to 93.67 million at monthly change rate 0.58 . At the same interval time period, mobile penetration increased from $106.72 \%$ to $107.17 \%$ at annual change rate 0.45 (Egyptian ministry of communication Report of, 2015).

According to The Statistical Portal (2016), the number of smart phone users is forecast to reach 2.08 billion in 2016, and the number of users worldwide is expected to pass the five billion mark by 2019. So, it's no wonder that mobile advertising will represent $72 \%$ of all US digital ad spending by 2019 .

By the end of 2020, the world will have over 55 million mobile devices, opening up huge possibilities and new types of applications for their users. Mobile technologies can be used for other tasks besides communication. They can allow consumers to acquire products and services, when they want and where they are (Coursaris; Sung: Swierenga, 2010).

From these indicators the researcher came to the result that while mobile marketing is an increasingly important promotional vehicle with some significant advantages over traditional media, many marketers have failed to use mobile marketing effectively. This poor performance is evidenced by high bounce rates, low completion rates, and poor average sales in comparison to laptop and desktop-based promotions.

To summarize, the research problem can be expressed in the following statement:

"Weak readiness of smart phone users to accept the marketing offers provided by the mobile in comparison to laptop and desktop-based promotions". 
The problem statement raises several questions:

$>$ What are the most important factors affecting consumer's readiness to accept marketing via mobile? And to what extent does the relative importance differ between these factors?

$>$ Is there any effect of these factors on the marketing via mobile acceptance?

\section{2-Research objectives:}

According to what have been demonstrated so far, this study aims mainly to reach the following objectives:

1- To identify the type and strength of the relationship between marketing via mobile and factors affecting consumers' acceptance.

2- Determine factors that have the most influential effect on marketing via mobiles.

3- Determine if there are any differences among undergraduate students' perception regarding factors affecting consumers' acceptance of mobile marketing in terms of their demographic characteristics (gender, age, education).

4- Develop a new model of marketing via mobiles in the online networking environment to enhance theory and contribute to the body of research on mobile marketing acceptance.

\section{3-Research Importance:}

1. According to the knowledge of the researcher, there is a little research published in the area of consumers' acceptance of marketing via mobiles.

2. The results of such research would help mobile advertisers design various interactive tools to increase accepting mobile advertising on web sites and webpages, also would allow marketers to directly send pictures or videos of products and to answer customer questions and queries. So, this research can help both of them to effectively communicate with each other's.

3. This quantitative study extends the academic knowledge of marketing via mobiles by testing whether some factors influence 
consumers' readiness to Accept Marketing via mobiles some but not others.

4. This research will give mobile advertisers information regarding critical variables that have influenced a consumer to accept an advertisement via mobiles, to increase this acceptance and therefore reduce wastage of media spending.

5. The study will provide useful information to marketers who will able to access several consumers at any time and establish close relations with consumers and this helps to influence purchase, also helps consumers to access to wide range of diverse information about varied products and services.

\section{4- Research hypotheses :}

H1: There is no significant relationship between consumer's readiness factors (providing information, risk avoidance, customer innovativeness, perceived usefulness, accessing content, demographic differences) and marketing via mobile acceptance.

$\mathrm{H} 2$ : Consumer's readiness factors have the same impact on marketing via mobile acceptance.

H3: Marketing via mobile acceptance not significantly differs according to consumer's demographics (age, gender, education and place). 
Figure (1) Research Conceptual Model Independent variables

\section{Dependent variable}

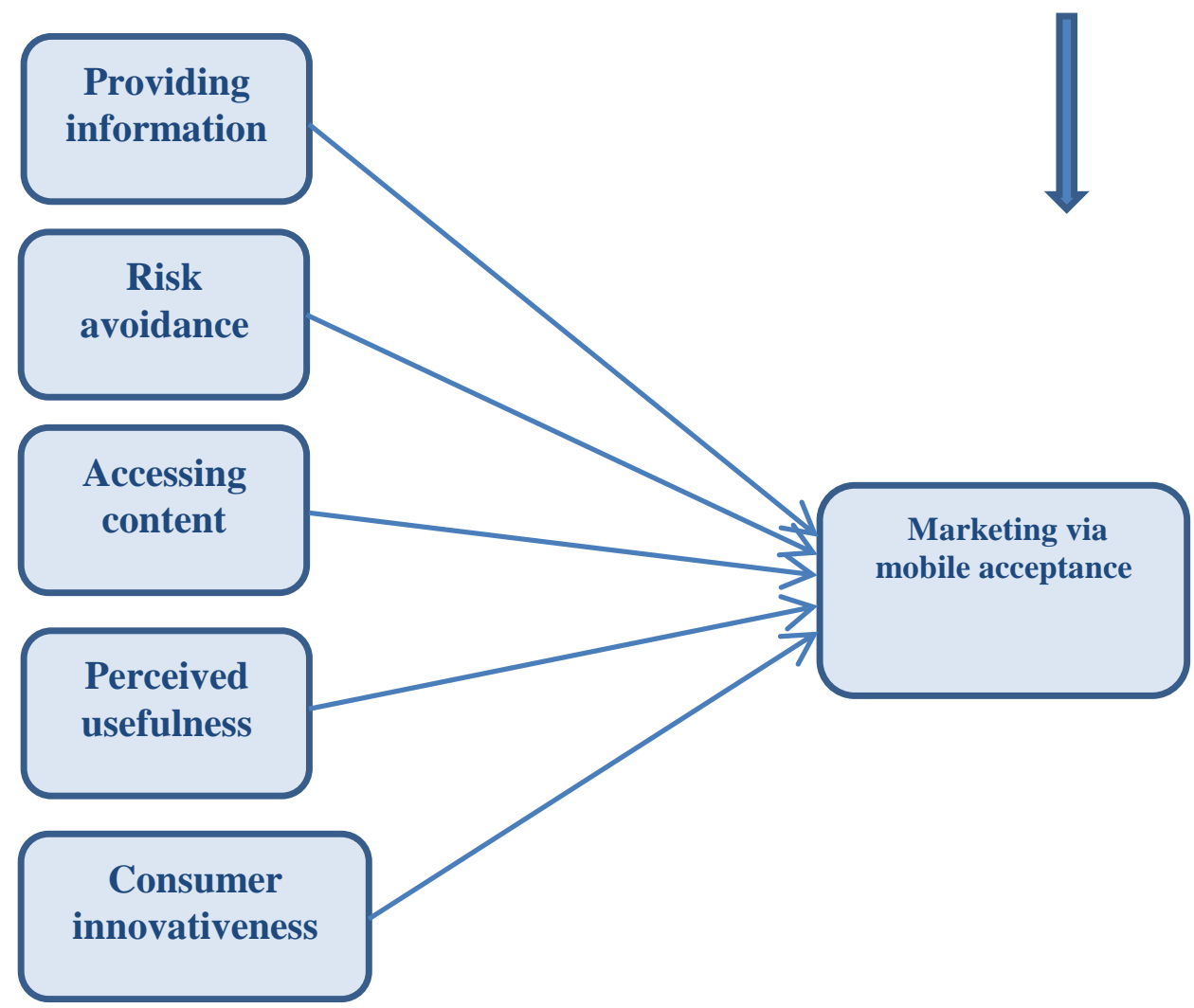

Source prepared by researcher according to literature review

\section{5-Research limitations}

Academic limitation: The study will focus only on investigating six main factors affecting marketing via mobiles acceptance, other factors will be excluded that could contribute to explaining the problem of the study.

Field limitation: 
The study will be applied on two universities in Egypt; one of which belong to the governmental sector (Zagazig University) and the other belong to the non-governmental sector (Future University).

(1.2) Research literature:

(A) Framework

1. Mobile marketing

Some scholars define mobile marketing as the use of mobile to personal information; provide others with specific locations, one-to-one communication, and for entertainment (Bauer, 2005; Gao et al., 2010).

The Mobile Marketing Association (MMA), a global spearhead in stimulating mobile marketing through mobile devices labels mobile marketing as, "the usage of wireless media as an integrated content delivery and direct response vehicle within a cross media marketing communication program" Vatanparast (2010). Keegan and Schlegelmich, (2001) explained that marketing distribution channels can be regarded as the method which is used for enterprises placing products into the market for consumers to use. Marketers need to defined tactics aimed at driving some awareness to attract the interest of their customer base and prospects. Some of the channels that marketers can consider using in distributing their products to consumers using the mobile platform are:

- Short Message Services

- Multi-media Services (SMS/MMS)

- Mobile Web

- Mobile Applications (mobile apps)

- Mobile Ads

- Mobile Tagging

- Quick Response (QR) Codes

Mobile marketing is a set of marketing practices that use wireless mobile technologies and networks to create personalized and interactive communication between an organization and its target audience, resulting in value creation for both parties Maduku(2016). 
Marketing via mobile is the use of wireless media as a delivery of an integrated content and a direct interaction means in a cross-media marketing communication program and in a world where everything is mobile, more and more people talk about the any area anywhere, anytime, any device, any channel, any product, any event and any me (Mobile Marketing Association, 2008).

The mobile marketing Association recently redefined marketing via mobile as "a set of practices that enables organizations to communicate and engage their audience in an interactive manner through any mobile device or network". Sometimes mobile marketing is called wireless marketing (MMA, 2011).

\section{Factors affecting the readiness of consumers}

Since mobile communication is readily available from any place and at any time, it creates some value through its convenience (Mohammed, 2010). This offers some businesses with the special ability to market at any time and location. past studies have focused their analysis of mobile marketing acceptance on various consumer characteristics, such as demographics (Muk \& Chung, 2015; Ünal, Erciş, \& Keser, 2011), innovativeness (Feng et al., 2016), and risk avoidance (Sultan et al., 2009). Nevertheless, according to Persaud and Azhar (2012) only studying the influence of these characteristics is insufficient, because there are other variables also need to be examined. The researcher identified three distinct dimensions of mobile marketing acceptance, which are providing information, accessing content, and perceived usefulness. For explaining consumer acceptance of mobile marketing this study factors are different from previous mobile marketing acceptance in that they pertain specifically to things that might prime or condition consumers toward acceptance of marketing via mobiles.

The researcher suggests that continued consumer acceptance of mobile marketing practice in a large and influential market such as Egypt will be driven by six antecedent factors including (Perceived usefulness,

Providing information, Consumer innovativeness, Risk avoidance, Accessing content and Demographic variables) these factors are drawn 
from two theoretical areas (the technology acceptance model (TAM) and uses and gratifications theory) which study the interaction between users and technology, and have been widely applied in the marketing literature to explain individual behavior related to the adoption and usage of technology.

\section{(B) Literature Review}

\section{Previous studies}

There have been extensive international researches that examine and analyze the importance and influence of the factors affecting consumers' readiness to accept marketing via mobiles. These studies provide the theoretical basis for this study.

Bauer et al. (2005) identified that attitude, social norm and perceived value are the critical success factors of marketing via mobile acceptance while Cheong \& Park (2005) found that the critical factors for the acceptance are attitude, perceived value, and perceived enjoyment.

Nysveen et al. (2005) mentioned that perceived expressiveness, normative pressure, ease of use, perceived usefulness, perceived enjoyment, and behavioral control are the success factors of marketing via mobile acceptance, while Rohm \& Sultan (2006) pointed out that the factors are risk avoidance, permission to interact, attitude, usage properties, and innovativeness.

According to Hong et al. (2008) the most influential factors for marketing via mobile acceptance are attitude, ease of use, and perceived enjoyment. Amin (2008) considered that amount of information, Perceived usefulness, Ease of use, perceived Credibility are the critical success factors for marketing via mobile acceptance; however, Sultan et al (2009) showed that risk acceptance, providing information, accessing content ,personal attachment are the most critical success factors of marketing via mobile acceptance.

On the other hand, Jayasingh \& Eze (2009) found that perceived usefulness, perceived credibility, social influence are the key drivers of marketing via mobile acceptance, while according to Bosnjak et al (2010) the main antecedents of marketing via mobiles acceptance are perceived 
usefulness, perceived value, enjoyment, trust, perceived cost, attitude, personal attachment and self-harmony.

Gao et al. (2010) suggested that accessing content, sharing content, providing information, risk acceptance, personal attachment are considered valuable motivations that lead to marketing via mobile acceptance. However, Ashraf \& Kamal (2010) demonstrated that permission to interact, usage properties, privacy, personal attachment, attitude\& innovativeness are the key motivators of marketing via mobile acceptance. Ismail\&Razak (2011) illustrated that perceived usefulness, subjective norm, attitude, ease of use, family \& friends, perceived enjoyment, perceived image are factors that lead to marketing via mobile acceptance. while Du Peng (2012) pointed out that risk degree, accessing Content, sharing content, personal attachment, providing information are leading factors to mobile marketing acceptance.

Furthermore Parreño et al. (2013) concluded that attitude, irritation, perceived usefulness, entertainment are the most antecedents factors of marketing via mobile acceptance. On the other hand, Chinomona \& Sandada (2013) indicates that antecedents of marketing via mobile acceptance are providing information, sharing content and accessing content. According to Al-Meshal and Almotairi (2013) the key indicators of marketing via mobile acceptance are providing information, accessing content, personal attachment, perceived value and sharing content.

While Gao et al (2013) found that ease of use, personal attachment, perceived usefulness, risk avoidance, innovativeness, and attitude are the main indicators marketing via mobile acceptance.

In addition to , AL- Khasawneh and Shuhaiber (2013) investigate that the major factors of marketing via mobile acceptance are providing information, enjoyment, privacy, brand familiarity, personalization, subjective norms, incentives, consumer control, and clarity. Toraih\& AlSaeed (2014) identified that the most major success factor of mobile marketing acceptance are ease of use, privacy, providing information, accessing content, sharing content, and risk acceptance.

Gao\&Zang (2015) found that entertainment, personalization, incentives, irritation, attitude, and credibility are considered as the most influential factors of marketing via mobile acceptance. Finally, according 
to Muk\& Chung (2015) the key factors of marketing via mobiles acceptance are entertainment, irritation, personalization, attitude, incentive, and credibility.

\section{Commenting on previous studies}

By reviewing studies that explored the area of accepting mobile marketing by consumers, the researcher came to a set of results.

- These previous studies were conducted within the time period from 2005 to the present time in various countries and territories including Arab Countries.

-There is a general agreement between researchers about mobile marketing as a constant companion to the consumer, a gateway to a relationship between the consumer and the retailer, making it an ideal supplementary channel for distance selling and physical retailing. Instead a limited number of studies presented findings on describing best demonstrated practice on how to implement successful mobile marketing from a single media or channel perspective, and how firms could realize potential in mobile marketing, and resources and competences to facilitate such actions.

-There is a general difference between previous studies in terms of numbers of factors employed in explaining mobile marketing acceptance; some used two or three antecedents while other studies used ten variables in explaining acceptance.

-This study is similar to previous studies in its effort to investigate the most important factors that may affect the readiness of consumers to accept marketing via mobile.

-In general, this study differs from previous studies as it employed seven factors that explained the readiness of consumers to accept marketing via mobile, to build a comprehensive model of variables explaining mobile marketing, this yielded a significantly higher explained variance than previous mobile marketing acceptance studies and also in the field where the study will be applied.

- In specific, the research employed new variable demographic differences as a factor that may affect mobile marketing that has been looked at in the context of traditional media (TV, radio, magazine) but not in marketing via mobile. 
- According to the knowledge of the researcher there is no any study about that topic in the Arabic area. So this study will be the first one within the context of Egyptian culture.

(1.3) Research Methodology:

1- Research Method:-

The present research adopts the quantitative research method as this research is considered descriptive in nature and the researcher wants to get the benefits of applying the quantitative research method.

\section{2-Research Population and Sample:-}

(a) Research population:-

The target population for this research was basically composed of young Egyptian mobile users represented in undergraduate students in the selected universities as follows; (Zagazig University, Future University).

(b)Sample and Sampling procedures:-

The sample method utilized was non- probability sampling.. The sample was divided disproportionally between the two universities because the disparity between their sizes was put into consideration.

\section{3-Data Collection methods:-}

The researcher started to distribute the questionnaire translated into Arabic among respondents by using an on-line survey to collect data as the research topic is highly relevant to the medium used, and it enabled quick and accurate gathering of survey information with minimal cost.

Table (1) Response rate of distributed questionnaires:

\begin{tabular}{|r|c|c|c|}
\hline Sector & Governmental & Non governmental & Total \\
\hline Distributed & 220 & 220 & 440 \\
\hline Returned & 216 & 212 & 428 \\
\hline Valid & 200 & 187 & 387 \\
\hline Response rate & $92 \%$ & $88 \%$ & $90 \%$ \\
\hline
\end{tabular}

Source: prepared by researcher 


\section{4-Instrumentation:-}

The instrument of collecting data for this study was a questionnaire that consisted of three major parts. (A); marketing via mobiles acceptance.

(B); factors affecting the acceptance.(C); asked for personal information.

The answers could be given by using a five-point Likert scale ranging from $1=$ strongly disagree to, $5=$ strongly agree.

Finally, Reliability and validity tests were performed on the research instrument using the SPSS Cronbach Alpha test. The results came back with alpha coefficients of more than (0.7) and total Validity is (0.859) which indicated high reliability and validity.

5-Research variables:-

\section{Dependent variable :-}

-Marketing via mobile acceptance

Independent variables:-

-Providing information

-Risk avoidance

- Customer innovativeness

-Perceived usefulness

-Accessing content

6-The Reliability and Validity of the Questionnaire:-

The results of reliability analysis revealed that most of item-total correlations were above 0.30 for all items in the questionnaire.

On the other hand, alpha coefficients were more than 0.60 for all scales used in the questionnaire which is acceptable and assure the internal consistency between items in the questionnaire. 
Also, the study results come back with the total coefficient of stability (alpha cronbach) for the total questioner is (0.739) and total Validity is (0.859) which indicated high reliability and validity.

7- Statistical techniques:-

Data analysis was implemented by program (SPSS) version 20 using the following statistical techniques.

- Central Tendency Measures.

- Measures of Dispersion.

- Reliability Analysis (Alpha Correlation Coefficient)

- Correlation Analysis (Pearson correlation coefficient )

- Multiple Regression analysis (linear).

- T-test and F- test

- One - Way Analysis of variance (One - Way ANOVA)

- Tukey Post hoc test

\section{(1.4)Data testing \& analysis:}

Testing the Study's Hypotheses:

Research Hypothesis 1 :

H01:"There is no significant relationship between consumer's readiness factors and marketing via mobile acceptance".

The results indicated in Table (2) are as follows:-

H1.1: There is a positive relationship between Mobile Marketing Acceptance and providing information. The correlation coefficient (0.464) it was statistical significance at level 0.01 .

H1.2: There is a positive relationship between Mobile Marketing Acceptance and accessing content. The correlation coefficient $(0.431)$ it was statistical significance at level 0.01 .

H1.3: There is a positive relationship between Mobile Marketing Acceptance and Risk avoidance. The correlation coefficient (0.201) it was statistical significance at level 0.01 .

H1.4: There is a positive relationship between Mobile Marketing Acceptance and Customer innovation. The correlation coefficient $(0.373)$ it was statistical significance at level 0.01 . 
H1.5: There is a positive relationship between Mobile Marketing Acceptance and Perceived usefulness. The correlation coefficient $(0.446)$ it was statistical significance at level 0.01 .

Table (2) correlation between Mobile Marketing Acceptance and both of (providing information, accessing content, Risk avoidance ,Customer innovation, Perceived usefulness).

\begin{tabular}{|c|c|c|}
\hline Items & Pearson Correlation & Sig. (2-tailed) \\
\hline providing information & $0.464^{* *}$ & 0.000 \\
\hline accessing content & $0.431^{* *}$ & 0.000 \\
\hline Risk avoidance & $0.201^{* *}$ & 0.000 \\
\hline Customer innovation & $0.373^{* *}$ & 0.000 \\
\hline Perceived usefulness & $0.446^{* *}$ & 0.000 \\
\hline
\end{tabular}

Source: statistical results .

H02: "Consumer's readiness factors have the same impact on marketing via mobile acceptance". Table (3) shows the values of independent variables coefficient and found that the model variables are statistically significant at a confidence level (0.95).

As a result, the null hypothesis is rejected and the alternative hypothesis that the independent variables have real value coefficients different from zero is accepted and they have areal impact on mobile marketing acceptance.

As a result, the null hypothesis is rejected and the alternative hypothesis that Consumer's readiness factors have not the same impact on marketing via mobile acceptance. 
Table (3) Model Summary

Model Summary

\begin{tabular}{|c|c|c|c|c|}
\hline Model & $\mathrm{R}$ & $\mathrm{R}$ Square & $\begin{array}{c}\text { Adjusted R } \\
\text { Square }\end{array}$ & $\begin{array}{c}\text { Std. Error of the } \\
\text { Estimate }\end{array}$ \\
\hline 1 & .840 & .707 & .698 & 7.19434 \\
\hline
\end{tabular}

a. Predictors: (Constant), perceived usefulness, Risk avoidance, providing information, customer innovation, accessing content

Source: statistical results.

From table (3) it is clear that total correlation (R) was $(0.840)$ This correlation is medium, the coefficient of determination (Adjusted $\mathrm{R}$ Square) was (0.698) that mean the independent variables explain $69.8 \%$ of any changes in Mobile Marketing Acceptance, the regression model is statistically significant when the F-test was (42.387) it significant at level (0.01).

Table (4) the values of independent variables coefficient.

\begin{tabular}{|c|c|c|c|c|c|c|}
\hline \multicolumn{7}{|c|}{ Coefficients $^{a}$} \\
\hline \multirow{2}{*}{\multicolumn{2}{|c|}{ Model }} & \multicolumn{2}{|c|}{$\begin{array}{l}\text { Unstandardized } \\
\text { Coefficients }\end{array}$} & \multirow{2}{*}{$\begin{array}{c}\text { Standardized } \\
\text { Coefficients } \\
\text { Beta }\end{array}$} & \multirow[b]{2}{*}{$\mathrm{t}$} & \multirow[b]{2}{*}{ Sig. } \\
\hline & & B & Std. Error & & & \\
\hline \multirow[t]{6}{*}{1} & (Constant) & 12.921 & 3.704 & & 3.488 & .001 \\
\hline & providing information & 0.494 & .057 & .272 & 8.667 & .000 \\
\hline & accessing content & 0.292 & .061 & .173 & 4.787 & .000 \\
\hline & Risk avoidance & 0.197 & .048 & .091 & 4.104 & .000 \\
\hline & customer innovation & 0.371 & .081 & .097 & 4.580 & .000 \\
\hline & perceived usefulness & 0.237 & .064 & .117 & 3.703 & .001 \\
\hline
\end{tabular}


The previous table (4) shows the null hypothesis is rejected and alternative hypothesis accepted; that the independent variables affect Mobile Marketing Acceptance.

H03: Marketing via mobile acceptance not significantly differs according to consumer's demographics (age, gender, education and place).

H3.1: Marketing via mobile acceptance not significantly differs according to consumer's education (governmental sector, nongovernmental sector). table (5) showed that: There are significant differences between the governmental sector and the nongovernmental sector in the Mobile Marketing Acceptance in favor of the nongovernmental sector. The average of the Mobile Marketing Acceptance was 56.71 degrees, with Standard deviation about 8.19 degrees, while the average of the Mobile Marketing Acceptance in the governmental sector was 52.13, with Standard deviation about 8.38 There was an increase in the average of the Mobile Marketing Acceptance about 4.58 in favor of the nongovernmental sector. This increase was significant Where the value of " $\mathrm{T}$ " about 5.435, which have a statistical significance at level 0.01 .

Table (5) Results of a significant test of the differences between the respondent's governmental sector and the nongovernmental sector in readiness to Accept Marketing via Mobiles.

\begin{tabular}{||c|c|c|c|c|c|c|c|}
\hline \multirow{2}{*}{ Items } & \multicolumn{1}{|c|}{ Sector } & $\mathrm{N}$ & Mean & $\begin{array}{c}\text { Std. } \\
\text { Deviation }\end{array}$ & $\begin{array}{c}\text { Std. Error } \\
\text { Mean }\end{array}$ & t-test & $\begin{array}{c}\text { Sig. (2- } \\
\text { tailed) }\end{array}$ \\
\hline $\begin{array}{l}\text { Mobile } \\
\text { Marketing } \\
\text { Acceptance }\end{array}$ & nongovernmental & 187 & 56.7112 & 8.18549 & .59858 & 5.435 & 0.000 \\
\cline { 2 - 8 } & Governmental & 200 & 52.1300 & 8.37999 & .59255 & & \\
\hline
\end{tabular}

Source: statistical results

H3.2: Marketing via mobile acceptance not significantly differs according to consumer's gender (male, female).

Table (6) showed that: There are Non-significant differences between the male and the female in the Mobile Marketing Acceptance in favor of male. The average of the Mobile Marketing Acceptance was 54.54 degrees, with Standard deviation about 8.58 degrees, while the average of the Mobile Marketing Acceptance in the female was 54.03, 
with Standard deviation about 8.45 There was an increase in the average of the Mobile Marketing Acceptance about 0.51 in favor of the male. This increase was Non-significant Where the value of "T" about 0.570 .

Table (6) Results of a significant test of the differences between the Male and the Female in readiness to Accept Marketing via Mobiles.

\begin{tabular}{|c|c|c|c|c|c|c|c|}
\hline & القطاع| & $\mathbf{N}$ & Mean & $\begin{array}{c}\text { Std. } \\
\text { Deviation }\end{array}$ & $\begin{array}{c}\text { Std. Error } \\
\text { Mean }\end{array}$ & t-test & $\begin{array}{l}\text { Sig. (2- } \\
\text { tailed) }\end{array}$ \\
\hline \multirow{2}{*}{$\begin{array}{l}\text { Mobile Marketing } \\
\text { Acceptance }\end{array}$} & Male & 239 & 54.5397 & 8.68094 & .56152 & \multirow[t]{2}{*}{0.570} & \multirow[t]{2}{*}{.569} \\
\hline & Female & 148 & 54.0270 & 8.45391 & .69491 & & \\
\hline
\end{tabular}

Source: statistical results

H3.3: Marketing via mobile acceptance not significantly differs according to consumer's ages. Table (7) showed that there are significant differences between ages of the respondents in the Mobile Marketing Acceptance in favor of ages 19-20, the average of the Mobile Marketing Acceptance was 60.06 degrees, with Standard deviation was about 6.19 degrees.

While the average of the Mobile Marketing Acceptance in the (2122) was 53.92, with Standard deviation about 7.91, while the average of the Mobile Marketing Acceptance in the 23-24 was 53.58, with Standard deviation about 7.74, while the average of the Mobile Marketing Acceptance in the 17-18 was 48.94, with Standard deviation about 10.58, There was significant increase in the average of the Mobile Marketing Acceptance favor of ages 23-24, Where the value of "F" about 20.349 which have a statistical significance at level 0.01 . 
The Antecedents Of Effective Mobile Marketing

For Strengthening Consumers' Chances Of Mobile

.Marketing Acceptance

Table (7) Results of a significant test of the differences between the ages of the respondents in readiness to Accept Marketing via Mobiles.

\begin{tabular}{|c|c|c|c|c|c|c|c|}
\hline Items & Age & $\mathrm{N}$ & Mean & $\begin{array}{c}\text { Std. } \\
\text { Deviation }\end{array}$ & $\begin{array}{l}\text { Std. } \\
\text { Error }\end{array}$ & $f$ & Sig \\
\hline \multirow{5}{*}{$\begin{array}{c}\text { Mobile Marketing } \\
\text { Acceptance }\end{array}$} & $17-18$ & 51 & 48.9412 & 10.58378 & 1.48203 & \multirow{5}{*}{20.349} & \multirow{5}{*}{.000} \\
\hline & $19-20$ & 72 & 60.0556 & 6.19834 & .73048 & & \\
\hline & $21-22$ & 192 & 53.9219 & 7.91375 & .57113 & & \\
\hline & 23-24 & 72 & 53.5833 & 7.74733 & .91303 & & \\
\hline & Total & 387 & 54.3437 & 8.58745 & .43652 & & \\
\hline
\end{tabular}

Source: statistical results

H3.4: Marketing via mobile acceptance not significantly differs according to consumer's Places of residence (Capital, center, city and village).

Table (8) Results of a significant test of the differences between the respondent's Places of residence in Readiness to Accept Marketing via Mobiles.

\begin{tabular}{|c|c|c|c|c|c|c|c|}
\hline Items & Age & $\mathbf{N}$ & Mean & $\begin{array}{c}\text { Std. } \\
\text { Deviation }\end{array}$ & $\begin{array}{l}\text { Std. } \\
\text { Error }\end{array}$ & $f$ & Sig \\
\hline \multirow{5}{*}{$\begin{array}{c}\text { Mobile Marketing } \\
\text { Acceptance }\end{array}$} & Village & 122 & 52.5738 & 9.36312 & .84770 & \multirow{5}{*}{4.641} & \multirow{5}{*}{.003} \\
\hline & City & 94 & 53.9043 & 7.84400 & .80905 & & \\
\hline & Center & 80 & 54.6625 & 8.30120 & .92810 & & \\
\hline & Capital & 91 & 56.8901 & 7.95327 & .83373 & & \\
\hline & Total & 387 & 54.3437 & 8.58745 & .43652 & & \\
\hline
\end{tabular}

Source: statistical results.

Table (8) showed that there are significant differences between Place of residence in the Mobile Marketing Acceptance in favor of Capital, The average of the Mobile Marketing Acceptance was 56.89 degrees, with Standard deviation about 7.95 degrees, while the average of the Mobile 
Marketing Acceptance in the center was 54.68, with Standard deviation about 8.30, while the average of the Mobile Marketing Acceptance in the city was 53.90, with Standard deviation about 7.84.

while the average of the Mobile Marketing Acceptance in the village was 52.57, with Standard deviation about 9.36, There was significant increase in the average of the Mobile Marketing Acceptance favor of Capital, where the value of "F" about 4.641 which have a statistical significance at level 0.01 .

(1.5) Results \& Recommendations:

(A) Results:

1. There is a positive relationship between the acceptance of mobile marketing and the factors (Providing information, risk avoidance, customer innovativeness, perceived usefulness, accessing content, demographic differences).

2. There is a positive relationship between Mobile Marketing Acceptance and accessing content

3. There is a positive relationship between Mobile Marketing Acceptance and risk avoidance.

4. There is a positive relationship between Mobile Marketing Acceptance and customer innovativeness.

5 .

ere is a positive relationship between Mobile Marketing Acceptance and perceived usefulness.

6. Consumer's readiness factors have different impact on marketing via mobile acceptance.

7. Marketing via mobile acceptance significantly differs according to consumer's demographics (age, gender, education and place).

8. There are significant differences between the students of governmental sector and the nongovernmental sector toward Mobile Marketing Acceptance in favor of the nongovernmental sectors.

9. There are not significant differences between the male and the female toward Mobile Marketing Acceptance in favor of male.

10. There are significant differences between ages of the respondents toward Mobile Marketing Acceptance in favor of ages (19-20). 
11. There are significant differences between Places of residence in the Mobile Marketing Acceptance in favor of Capital.

12. The main conclusion is that all the research constructs (providing information, customer innovativeness, accessing content, perceived usefulness, risk avoidance) have a significant influence on mobile marketing acceptance.

13. Another key finding from the research is that there are Nonsignificant differences between the male and the female in the Mobile Marketing Acceptance but there is differences in favor of male .This is further revealed as most respondents preferred to receive only one marketing message per day whilst a sizeable proportion did not want to receive mobile marketing notifications at all as they consider the messages annoying.

14. The mobile advertising industry impacts a consumer every time a new message is received by the customer. This is especially relevant since mobile is such a personal medium and is always present with the customer. Unlike other media an advertising message on mobile is to be received first even if the consumer does not read or pay attention to the message.

\section{(b)Recommendations:-}

1. Mobile marketers must take care that if users feel their privacy has been violated they will avoid the ads risk, they must state clearly how their information collected and used and keep them up to date with privacy changes.

2. Mobile advertisers must design various interactive tools to increase accepting mobile advertising on web sites and webpages, also would allow they should directly send pictures or videos of products and to answer customer questions and queries so; both of them can effectively communicate with each other's.

3. Mobile advertisers must build trust in their information they introduce and collected through ads, make sure of the sufficiency of 
their information and confirm that their ads provide a true picture of their products.

4. Advertisers should make their ads useful for users as much as they can, to make their ads related to the users personality, matching with their values, opinion and attitudes.

5. Mobile marketers must take into consideration the nature of mobile. It is a place of social interaction more than a place of commercial exchange. So, they should deliver a small number of highly targeted ads instead of a large number of advertisements .

6. Mobile Marketers should track their conversion rates and understand their market better, because mobile device users often send their feedback immediately.

7. Risk perception in the context of mobile marketing mainly results from the fear of data misuse and the reception of unwanted mobile marketing messages

8. Marketers should definitely be advised against using impersonalized mass messages for communicating advertising content.

(1.6 ) Opportunities for Further researchers:-

The researcher suggested the following pointes :

- It would be useful to conduct an experimental study that directly measures actual acceptance readiness through mobile.

- A comprehensive study will be needed to examining the effect of different acceptance reasons.

- Further research is also needed on the concept of permission marketing. 
- Finally, cross-cultural studies in the domain of mobile marketing are still quite scarce.

\section{REFRERANCES:}

- Aaker D., Kumar V., \& Day G. (2007), "Marketing Research", 9th edition, Wiley.

- Ajzen, I., \& Fishbein, M. (1980). Understanding attitudes and predicting social behaviour. Eaglewood Cliffs, NJ: Prentice-Hall.

- AL- Khasawneh, Mohammad and Shuhaiber, Ahmed (2013) "A Comprehensive Model of Factors Influencing Consumer Attitude Towards and Acceptance of SMS Advertising: An Empirical Investigation in Jordan" International Journal of Sales \& Marketing Management Research and Development (IJSMMRD), Vol.3, Issue 2, pp. 1-22.

- Al-Meshal, Soad and Almotairi, Mohammad (2013) "Consumer acceptance of Mobile Marketing: An Empirical Study on the Saudi Female" International Journal of Marketing Studies, Vol. 5, No. 5, pp. 94-100.

- Amato, C.H., Hollenbeck, C, R., and Peters, C. (2007). An Exploratory Investigation of Consumers Perceptions of Wireless Advertising. Journal of Advertising, Vol.36 No.4, pp. 129-145.

- Amin Mohamed Ahmed (2014), "The role of the customer initiative in the development of the intentions of adopting new products applied study on mobile customers for Egyptian university students", Ph.D. Thesis, Faculty of Commerce - Mansoura University. (In Arabic).

- Anderson and Nilsson. (2000). Wireless Advertising Effectiveness: Evaluation of an SMS advertising Trial. [Online] Available:http:// web.hhs.se/cic/courses/ underthebridge/wireless_ad_eff.pdf. 
- Andreas M. (2012). If you love something, let it go mobile: Mobile marketing and mobile social media 4x4, Business Horizons, Vol. 55 No .2, pp. 129-139.

- App Annie, (2015). Complete app market to uncover opportunities without the guesswork. Available from https://www.appannie.com/ en/tours/market-dataintelligence/.

- Ashraf, M. F., \& Kamal, Y. (2010). Acceptance of mobile marketing among university students. Mustang Journal of Business and Ethics, 1, 9.

- Ayanwale, A., Alimi, T., and Ayanbimipe, M. (2005). The Influence of Advertising on Consumer Brand Preference. Journal of Social Sciences, Vol. 10, 1, 9-16.

- Balasubramanian, S., Peterson, R. A., \& Jarvenpaa, S. L. (2002). Exploring the implications of $\mathrm{m}$-commerce for markets and marketing. Journal of the Academy of Marketing Science, 30(4).

- Barnes, S.J. (2003), "Location-Based Services: The State-of-the-Art", eService Journal, Vol. 2, No. 3: 59-70,

- Barutcu, S .(2007). Attitudes towards mobile marketing tools: a study of Turkish consumers. Journal of Targeting, Measurement and Analysis for Marketing, Vol. 16 No. 1, pp. 26-38.

- Barwise , P., and Strong , C. ( 2002 ). Permission-based mobile advertising. Journal of Interactive Marketing, Vol. 16 ,1, 14 - 24

- Bauer, Hans; Barnes, Stuart; Reichardt, Tina and Neumann, Marcus (2005)'Driving consumer acceptance of mobile marketing .

- Carroll, A., Barnes, S. J., and Scornavacca, E. (2005). Consumers Perceptions and Attitudes towards SMS Mobile Marketing in New 
Zealand. In the Proceedings of the Fourth International Conference on Mobile Business (ICMB 2005), pp. 434-440.

- Carroll, A., Barnes, S. J., Scornavacca, E., \& Fletcher, K. (2007). Consumer perceptions and attitudes towards SMS advertising: recent evidence from New Zealand. International Journal of Advertising, 26(1), 79-98.

- Cheong, J., \& Park, M. C. (2005). Mobile internet acceptance in Korea. Internet research, 15(2), 125-140.

- Chinomona, Richard and Sandada, Maxwell (2013) "The Influence of Market Related Mobile Activities on The Acceptance of Mobile Marketing And Consumer Intention To Purchase Products Promoted By SMS In South Africa" The Journal of Applied Business Research, Vol. 29, No. 6,pp.1897-1907.

- Chiu, Y.B., Lin, C.P. and Tang, L.L. (2005), "Gender differs: assessing a model of online purchase intentions in e-tail service', International Journal of Service Industry Management, Vol. 16 No. 5, pp. 416-35.

- Chowdhury, H., K., Parvin, N., Weitenberner, C., and Becker, M., (2006). Consumer Attitude toward Mobile Advertising in an Emerging Market: An Empirical Study. International Journal of Mobile Marketing, Vol. 1 2, 33-42.

- Coursaris, C. K; sung, J; swierenga, S. J. (2010), Effects of Message Characteristics, Age, and Gender on Perceptions of Mobile advertising. In: International Conference on Mobile Business / Global Mobility Roundtable, 9, 2010, Atenas,Grecia. Anais. Atenas:.

- Davis FD (1989).Perceived Usefulness, Perceived Ease of Use and User Acceptance of Information Technology. MIS Q., 13(3):319-339. 
- Deloitte.(2013). Deloitee Forecast a big year for mobile in southAfrica. [Online]. At: http://businesstech.co.za/news/mobile/31978/.

- Deng, Z., Lu, Y., Wang, B., Zhang, J., \& Wei, K. K. (2010). An empirical analysis of factors influencing users' adoption and use of mobile services in China. International Journal of Mobile Communications, 8(5), 561-585.

- Dickinger A., Haghirian P., Murphy J., and Scharl A. (2004). An Investigation and Conceptual Model of SMS Marketing. Proceedings of the 37th Hawaii International Conference on System Sciences (HICSS37 , Hawaii,USA. [Online]Available:http://csdl.computer.org/comp/proceedings/hicss/200 4/2056/01/205610031b.pdf.

- Dix, S., Phau, I., Jamieson, K., \& Shimul, A. S. (2017). Investigating the Drivers of Consumer Acceptance and Response of SMS Advertising. Journal of Promotion Management, 23(1), 62-79.

- Doherty, C. (2007). Mobile Marketing is Yet to Bloom. Revolution, November, pp. 51.

- Du, Peng (2012) "Factors Influencing Consumers' Acceptance of Mobile Marketing: An Empirical Study of the Chinese Youth Market" International Journal of China Marketing, Vol. 2, No.2, pp.24-37.

- Duncan, E., Hazan, E., \& Roche, K. (2014, March). Digital disrup-tion: Six consumer trends and what businesses need to do now.

- Earl, M., \& Feeny, D. (2012). How to be a CEO for the information age. Sloan Management Review, 14(2), 11-23.

- Edress T.A, (2012). Marketing Research, Techniques of measurements, and analysis, and testing hypotheses. El-dar El-gameaya in Alexandria. (In Arabic). 
- eMarketer (2010, December). Local Mobile Ad Spending to ContinueDramaticGrowth.Retrievedfromhttp://www.emarketer.com/mo bile/ article_m.aspx?R=1008094.

- eMarketer (2011, February). Best Practices for Mobile Retail Strategy,eMarketer.Retrievedfromhttp://www.emarketer.com/Aticle.asp $\mathrm{x}$ ? $=1008221$. Mobile Marketing Association IJMM Summer 2012Vol. 7, No. 2.

- e-marketer. (2014). Driven by Facebook and Google, Mobile Ad Market Soars $105 \%$ in 2013.

- eMarketer. (2015). Mobile Ad Spend to Top \$100 Billion Worldwide in 2016, 51\% of Digital Market - eMarketer. Retrieved from https://www.emarketer.com /Article/Mobile-Ad-Spend-Top-100Billion-Worldwide-2016-51-of-Digital-Market/1012299.

- eMarketer. (2016). [Online]. Available at: www.emarketer.com. [Accessed on: 15 April 2016].

- E-Marketing Egypt (2016). Digital Marketing Outsourcing, Consulting \& Training Company in Egypt .available at http://www.emarketingegypt.com.

- Enpocket.(2002).The response performance of SMSadvertising. [Online]

Available:http://www.enpocket.com/resource/acrobat/Enpocket\%20Insi ght\%20-\%20Direct\%20response.pdf, accessed 19 June 2004.

- Ericson, L., Herring, L., \& Ungerman, K. (2014, December). Busting mobile-shopping myths. McKinsey and Company. From http://mckinseyonmarketingandsales. 
- Feng, X., Fu, S., \& Qin, J. (2016). Determinants of consumers' attitudes toward mobile advertising: The mediating roles of intrinsic and extrinsic motivations. Computers in Human Behavior, 63, 334-341.

- Content Marketing Institute (2018) What is Content Marketing? [online] http://contentmarketinginstitute.com/what-is-content-marketing/ (accessed 30 September 2018).

- Global Mobile Marketing Market to Reach $\$ 183.5$ Billion by 2024, with a CAGR of $23.4 \%$ - Analysis Segmented by Solution Type, Organization Size, End-user and Geography.

- Why Mobile and Consumers Are the Focal Points of This Year's NewFronts. Retrieved July 2, 2018, from adweek.com.

- Mobile Marketing Statistics for 2018 and Beyond | Mobile Usage Statistics. Retrieved July 2, 2018, from bluecororna.com.

- Grewal, L., \& Stephen, A. T. (2019). In Mobile we trust: The effects of Mobile versus nonmobile reviews on consumer purchase intentions. Journal of Marketing Research, 002224371983451.

- (2018). Chart: Mobile E-commerce is up and Poised for Further Growth. Retrieved July 1, 2018, from statista.com website: https://www.statista.com/chart/13139/estimated-worldwide-mobile-ecommerce-sales/.

- Number of Mobile Phone Users Worldwide 2015-2020. Retrieved May 3, 2019, from statista.com 


\section{Questionnaire}

Dear students /After Greetings...

You are being asked to take part in completing a questionnaire related to a study titled Factors Affecting Consumers' Readiness to Accept Marketing via Mobiles "An Applied study". Your participation is voluntary and responses will be confidential and used for the current research purpose only. Thank you ......

\section{Dear students /After Greetings...}

\section{Questionnaire}

You are being asked to take part in completing a questionnaire related to a study titled Factors Affecting Consumers' Readiness to Accept Marketing via Mobiles "An Applied study". Your participation is voluntary and responses will be confidential and used for the current research purpose only. Thank you ...... 
Question One:- Please think carefully about each statement.

\begin{tabular}{|c|c|c|c|c|c|}
\hline $\begin{array}{rr}\text { Opinion } \\
\text { Statement }\end{array}$ & $\begin{array}{l}\text { Strongly } \\
\text { Agree }\end{array}$ & Agree & Neutral & Disagree & $\begin{array}{l}\text { Strongly } \\
\text { Disagree }\end{array}$ \\
\hline $\begin{array}{l}\text { 1- I receive information about certain } \\
\text { products on mobile. }\end{array}$ & & & & & \\
\hline $\begin{array}{l}\text { 2- I receive offers on mobile from } \\
\text { companies related to an event I am } \\
\text { attending. }\end{array}$ & & & & & \\
\hline $\begin{array}{l}\text { 3- } \text { I receive solicitations from } \\
\text { companies to whom I gave my } \\
\text { permission. }\end{array}$ & & & & & \\
\hline $\begin{array}{l}\text { 4- like to take part in mobile } \\
\text { marketing promotions. }\end{array}$ & & & & & \\
\hline $\begin{array}{ll}\text { 5- } & \text { I receive mobile Ads Appear when I } \\
\text { search google. }\end{array}$ & & & & & \\
\hline $\begin{array}{l}\text { 6- I receive mobile information } \\
\text { products especially I am interested } \\
\text { in. }\end{array}$ & & & & & \\
\hline $\begin{array}{l}\text { 7- It important to receive a mobile } \\
\text { massage related to future lower price } \\
\text { products. }\end{array}$ & & & & & \\
\hline $\begin{array}{l}\text { 8- I receive a mobile promotions on } \\
\text { the latest of products versions. }\end{array}$ & & & & & \\
\hline $\begin{array}{ll}\text { I accept to receive mobile } \\
\text { promotions on the modern courses . }\end{array}$ & & & & & \\
\hline $\begin{array}{l}\text { 10- I interact with mobile marketing to } \\
\text { match the daily market place } \\
\text { requirements. }\end{array}$ & & & & & \\
\hline $\begin{array}{l}\text { 11- I think mobile marketing enhances } \\
\text { the seller and buyer relationship. }\end{array}$ & & & & & \\
\hline $\begin{array}{l}\text { 12- Mobile marketing aims at informing } \\
\text { the consumer about products. }\end{array}$ & & & & & \\
\hline $\begin{array}{l}\text { 13- I find mobile marketing means a lot } \\
\text { to me. }\end{array}$ & & & & & \\
\hline $\begin{array}{l}\text { 14- I accept mobile advertising as it } \\
\text { expand my products and } \\
\text { knowledge. }\end{array}$ & & & & & \\
\hline
\end{tabular}


The Antecedents Of Effective Mobile Marketing

For Strengthening Consumers' Chances Of Mobile

.Marketing Acceptance

\section{Question One:- Please think carefully about each statement.}

\begin{tabular}{|c|c|c|c|c|c|}
\hline $\begin{array}{r}\text { Opinion } \\
\text { Statement }\end{array}$ & $\begin{array}{l}\text { Strongl } \\
\text { y Agree }\end{array}$ & Agree & Neutral & Disagree & $\begin{array}{l}\text { Strongly } \\
\text { Disagree }\end{array}$ \\
\hline \multicolumn{6}{|l|}{$\begin{array}{l}\text { 15. I check my e-mail address using my } \\
\text { mobile. }\end{array}$} \\
\hline \multicolumn{6}{|l|}{$\begin{array}{l}\text { 16. I register with a website using my } \\
\text { mobile. }\end{array}$} \\
\hline \multicolumn{6}{|l|}{$\begin{array}{l}\text { 17. I register for a contest using my } \\
\text { mobile. }\end{array}$} \\
\hline \multicolumn{6}{|l|}{$\begin{array}{l}\text { 18. I register for promotion using my } \\
\text { mobile. }\end{array}$} \\
\hline \multicolumn{6}{|l|}{$\begin{array}{l}\text { 19. I provide my password to a website } \\
\text { via mobile to receive daily news. }\end{array}$} \\
\hline \multicolumn{6}{|l|}{$\begin{array}{l}\text { 20. I use my mobile to follow up the } \\
\text { movement of stock market. }\end{array}$} \\
\hline \multicolumn{6}{|l|}{$\begin{array}{l}\text { 21. I provide my demographics } \\
\text { information using mobile to dialogue } \\
\text { with the marketer. }\end{array}$} \\
\hline \multicolumn{6}{|l|}{$\begin{array}{l}\text { 22. I provide my financial data to enter to } \\
\text { interactive content using my mobile. }\end{array}$} \\
\hline \multicolumn{6}{|l|}{$\begin{array}{l}\text { 23. I provide my identity information to } \\
\text { take advantage of the customized } \\
\text { mobile ads. }\end{array}$} \\
\hline \multicolumn{6}{|l|}{$\begin{array}{l}\text { 24. provide my purchase history to benefit } \\
\text { from the reductions. }\end{array}$} \\
\hline \multicolumn{6}{|l|}{$\begin{array}{l}\text { 25. I provide my e-mail to a web sites } \\
\text { using mobile to get free connection } \\
\text { time in return. }\end{array}$} \\
\hline \multicolumn{6}{|l|}{$\begin{array}{l}\text { 26. I like download content such as } \\
\text { wallpaper using my mobile. }\end{array}$} \\
\hline \multicolumn{6}{|l|}{$\begin{array}{l}\text { 27. I frequently browsing and searching } \\
\text { content such as ringtone using my } \\
\text { mobile. }\end{array}$} \\
\hline $\begin{array}{l}\text { 28. I download useful applications such } \\
\text { as (OLX) using my mobile. }\end{array}$ & & & & & \\
\hline
\end{tabular}




\begin{tabular}{|c|c|c|c|c|c|}
\hline $\begin{array}{r}\text { Opinion } \\
\text { Statement }\end{array}$ & $\begin{array}{l}\text { Strongl } \\
\text { y Agree }\end{array}$ & Agree & Neutral & Disagree & $\begin{array}{l}\text { Strongly } \\
\text { Disagree }\end{array}$ \\
\hline \multicolumn{6}{|l|}{$\begin{array}{l}\text { 29. IAccess fun and } \\
\text { entertaining content such } \\
\text { as movies via mobile. }\end{array}$} \\
\hline \multicolumn{6}{|l|}{$\begin{array}{l}\text { 30. I like Access fun and } \\
\text { entertaining content such } \\
\text { as photos via mobile. }\end{array}$} \\
\hline \multicolumn{6}{|l|}{$\begin{array}{l}\text { 31. I Pay for content such as } \\
\text { games using mobile. }\end{array}$} \\
\hline \multicolumn{6}{|l|}{$\begin{array}{l}\text { 32. I Pay for content such as } \\
\text { ringtones using my } \\
\text { mobile. }\end{array}$} \\
\hline \multicolumn{6}{|l|}{$\begin{array}{l}\text { 33. I pay attention to Access } \\
\text { product information via } \\
\text { mobile. }\end{array}$} \\
\hline \multicolumn{6}{|l|}{$\begin{array}{l}\text { 34. I like to access to plenty } \\
\text { of programs on the } \\
\text { application store via } \\
\text { mobile. }\end{array}$} \\
\hline $\begin{array}{l}\text { 35. I like to access to } \\
\text { academic texts using } \\
\text { mobile web pages }\end{array}$ & & & & & \\
\hline
\end{tabular}

Question two:- Personal Information Kindly give the following information about yourself.

1- Gender:

\begin{tabular}{|l|l|l|l|}
\hline Male & & Female & \\
\hline
\end{tabular}

2- Age:

\begin{tabular}{|l|l|l|l|}
\hline $17-18$ & & $21-22$ & \\
\hline $19-20$ & & $23-24$ & \\
\hline
\end{tabular}


